\title{
Estrogen receptor $B$ and epidermal growth factor receptor as early-stage prognostic biomarkers of non-small cell lung cancer
}

\author{
LAURA VALERIA MAURO ${ }^{1}$, MERCEDES DALURZO ${ }^{2}$, MARIA JOSÉ CARLINI $^{1}$, DAVID SMITH ${ }^{2}$, \\ MYRIAM NUÑEZ ${ }^{2}$, MARINA SIMIAN ${ }^{1}$, JOSÉ LASTIRI ${ }^{2}$, BARTOLOMÉ VASALLO ${ }^{2}$, \\ ELISA BAL DE KIER JOFFÉ ${ }^{1}$, MARIA GUADALUPE PALLOTTA ${ }^{2}$ and LYDIA PURICELLI ${ }^{1}$ \\ ${ }^{1}$ Research Area of the Institute of Oncology 'Angel H. Roffo', University of Buenos Aires; \\ ${ }^{2}$ Hospital Italiano de Buenos Aires, Buenos Aires, Argentina
}

Received May 11, 2010; Accepted July 7, 2010

DOI: 10.3892/or_00000990

\begin{abstract}
As $20 \%$ of stage I NSCLC patients develop recurrent and often incurable cancer, the identification of prognostic markers has a meaningful clinical application. The biological significance of steroid hormone and EGF receptors, able to regulate key physiological functions, remains elusive in NSCLC. Our aim was to investigate the prognostic input of estrogen receptors (ER $\alpha, E R \beta)$, progesterone receptors (PR) and EGFR in tumors from 58 stage I NSCLC patients. Antigen expression was analyzed by immunohistochemistry. Prognostic evaluation was performed with the multivariate Cox model. We found that about 70 and $40 \%$ of samples expressed ER $\alpha$ or ER $\beta$ at cytoplasmic or nuclear level, respectively. Besides, only $12.1 \%$ of samples weakly expressed nuclear PR and $62.7 \%$ showed membrane EGFR staining. Correlation studies indicated an inverse association between EGFR expression and smoking status $(\mathrm{p}<0.01)$. Multivariate studies showed that the lack of nuclear ERß or the loss of EGFR expression were independent prognosis markers associated with shorter overall survival. We also found that patients whose tumors were negative for these two biomarkers presented the worst outcome. In conclusion, our findings could be useful for selecting stage I NSCLC patients with poor prognosis to apply an earlier treatment that impacts on survival.
\end{abstract}

\section{Introduction}

Lung cancer is the leading cause of cancer death in developed countries. The age-standardized mortality rates (per 100,000)

Correspondence to: Dr Lydia Puricelli, Research Area, Institute of Oncology 'Ángel H. Roffo', Av. San Martín 5481, C1417DTB Buenos Aires, Argentina

E-mail: lydiapur@fmed.uba.ar

Key words: estrogen receptor, progesterone receptor, epidermal growth factor receptor, non-small cell lung cancer, prognostic biomarker of this cancer for Argentina (period 1997-2001) were 35.0 and 6.7 cases in men and women, respectively, being the first cause of cancer-related death in men and the fourth in women (1).

Lung cancer is histologically classified into small cell lung carcinoma (SCLC) and non-small cell lung carcinoma (NSCLC). NSCLC accounts for approximately $80 \%$ of all cancer cases and represents a heterogeneous group which includes squamous cell carcinoma (SCC), adenocarcinoma (ADC) and large cell carcinoma. SCC is markedly associated with smoking and more frequently detected in males, but ADC tends to occur more frequently in females, suggesting a possible involvement of gender-dependent factors in the pathogenesis and/or development of NSCLC (2).

Clinicians face some difficulties in the management of lung cancer patients. First, patient survival has been shown to be mainly dependent on the stage of the disease at the time of diagnosis, being the rate of incidence practically equal to the rate of death when NSCLC is diagnosed at advanced-stages. It is also known that $20 \%$ of stage I and $30 \%$ of stage II patients develop recurrent cancer which is often incurable at the time of discovery. Second, few clinical factors are useful for assessing individual prognosis which are insufficient to predict the evolution of each patient (3). In this scene, it is of high priority to find tumoral markers able to identify a subset of patients with poor prognosis in order to apply an earlier therapy that may have impact on survival.

Among the key molecules able to regulate physiological cellular functions and modulate tumor progression are the steroid hormones. Their effects are mediated by specific receptors, belonging to the nuclear hormone receptors superfamily, which modulates the expression of genes involved in cell proliferation, apoptosis, invasion, angiogenesis and metastasis (4). There are two estrogen receptors, known as ERalpha $(\mathrm{ER} \alpha)$ and ERbeta $(\mathrm{ER} \beta)$, that can induce different biological responses (5-7), modulating gene expression in classical and non-classical ways (8). In addition, recent studies have described non-genomic ER actions, originated at extranuclear sites. It is known that ERs are concentrated in caveolae and lipid rafts, regions highly enriched with critical signaling molecules as EGFR and HER2 (9), and that membrane-initiated steroid signaling activity can result in 
activation of growth factor signaling pathways $(10,11)$. Thus, in some tumors, estrogens could be acting as a dominant factor by activating multiple pathways important in tumor progression. On the other hand, ERs can also be activated by crosstalk with growth factor receptors such as EGFR and IGFR (insulin growth factor receptor) via receptor phosphorylation $(12,13)$.

Progesterone receptor (PR) is codified by an estrogenregulated gene and its synthesis in normal and cancer cells requires estrogen and ER (14). It is known that the activation of PR induces differentiation and inhibition of cellular proliferation (15).

The expression of sex steroid receptors has been previously reported in non-traditionally estrogen responsive malignancies, such as osteosarcoma, hepatocarcinoma, colorectal, renal and pancreatic cancer $(16,17)$ as well as in NSCLC (18-30). However, their biological significance remains unclear.

The EGFR (HER-1 or erbB-1) is a transmembrane tyrosine kinase receptor that, in response to different ligands, can dimerize and mediate a series of signaling cascades via phosphorylations that culminate in the regulation of transcription factors and other proteins that control cell fate (31). The EGFR is mutated or overexpressed in many human cancers, including NSCLC tumors, and this often correlates with a more aggressive disease (32). This fact has been determinant for the approval of the EGFR receptor kinase inhibitor for clinical use in the treatment of advanced NSCLC as monotherapy following failure of chemotherapy (33). Furthermore, the crosstalk between EGFR and ER pathways in lung cancer could provide a rationale to combine inhibitors of EGFR activation with anti-estrogen therapy for the treatment of the disease $(9,34)$.

As the relationship between sex steroid receptors and EGFR has been poorly studied, our aim was to analyze the expression pattern of ER $\alpha, E R \beta, P R$ and EGFR in the primary tumor of a group of 58 patients with localized (stage I) NSCLC. Results were correlated with clinical and anatomo-pathological parameters accepted as established prognostic factors, including survival rate.

\section{Materials and methods}

Patients and tumors. Fifty-eight paraffin embedded NSCLC tumors, corresponding to the 1997-2004 period, were collected from the 'Hospital Italiano de Buenos Aires'. The study included Caucasian individuals, 40 men (median age, 64, range, 47-78) and 18 women $(66,51-83)$. All tissue specimens were obtained by surgery from untreated stage I patients at initial diagnosis and were classified morphologically employing the established WHO classification (2004). No patient received either chemo- or radiotherapy after surgery. Information about patients was obtained by review of their medical charts. Table I summarizes the clinico-pathological characteristics of the cases.

All patients who died $(n=14)$ had clear evidence of uncontrolled tumor growth at the time of death. This was assessed by different procedures carried out for each patient: computerized axial tomography and/or nuclear magnetic resonance (14/14) and confirmatory biopsy (2/14).
Table I. Clinico-pathological data of patients with NSCLC $(n=58)$.

Parameter

Positive cases $(\%)^{\mathrm{a}}$

Sex

Male

$40(69.0)$

Female

18 (37.0)

Age

$<60$

$14(24.6)$

60-69

$\geq 70$

Stage

IA

22 (37.9)

IB

Histological type

SCC

$33(57.9)$

$\mathrm{ADC}$

$18(31.6)$

Others

$6(10.5)$

Surgery

Lobectomy

$43(74.1)$

Bilobectomy

Pneumonectomy

Segmentectomy

Smoking habit

No

$16(28.1)$

Yes

$41(71.9)$

${ }^{a}$ Where columns do not sum to the total, data were missing or unknown.

The median follow-up for this homogeneous cohort was 48 months, with a range from 3 to 116 months.

The Ethic Committees of the Institute of Oncology 'Angel H. Roffo' and the 'Hospital Italiano de Buenos Aires' approved this study, having carefully followed the Helsinki Declaration.

Immunohistochemistry (IHC). Tumor specimens were fixed with $10 \%$ formaldehyde in phosphate-buffer solution (PBS) immediately after removal and processed to paraffin blocks. Representative serial sections ( $5 \mu \mathrm{m}$ thick) were placed on positively charged glass slides and microwaved in citrate buffer ( $\mathrm{pH}$ 6.0) to recover antigenicity. Sections were treated with $7 \%$ hydrogen peroxide in methanol for $20 \mathrm{~min}$ to block endogenous peroxidase activity. Then, sections were incubated with $5 \%$ milk in distilled water for 45 min to block nonspecific binding and incubated overnight at $4{ }^{\circ} \mathrm{C}$ with the following commercial primary antibodies: two different antiER $\alpha$ : NCL-ER-6F11 (Novocastra, Newcastle, UK) and sc543 (Santa Cruz Biotechnology, USA, which recognizes the $\mathrm{COOH}$ terminal of the ER), anti-PR (sc 539, Santa Cruz Biotechnology) and the monoclonal mouse anti-human 
EGFR (EFGR PHARM Dx K1494, Dako, USA). Anti-ER $\alpha$ and PR were used at 1/100 dilution in PBS, anti-ERß was used at 1/200 and anti-EGFR was used without dilution. Then, sections were incubated $1 \mathrm{~h}$ at room temperature with biotinylated anti-mouse or anti-rabbit antibody, according to the species of the first antibody (Gibco-BRL, Gaithersburg, USA). In the case of ERß a chicken polyclonal antibody was employed and it was a gift from Dr J.A. Gustafsson (Sweden). After washing, sections were treated with Vectastain ABC kit Universal (PK-6200, Vector Laboratories, Burlingame, USA) and then incubated with the chromogen 3,3'diaminobenzidine (DAB).

Finally, they were counterstained with Harris hematoxylin. Negative controls, missing out the first antibody or incubating with primary not related antibodies, were performed to discriminate background staining.

Besides, a breast cancer sample positive for ER and PR was always included as a positive control. The expression of the different antigens in NSCLC tumors was analyzed by three independent observers and was scored according to the number of positive cells with specific bright brownish staining. Disagreements in scorings (about 8\%) were resolved by revision and discussion with a multiheaded microscope. Pathologists were blinded to all subject characteristics and survival status.

Review of paired normal and tumor tissue was difficult because of the lack of adjacent normal tissue in most blocks. Differences in the intensity of staining were not considered.

The labeling index for each antigen was calculated as the percentage of labeled cells out of the total number $(n=1500)$ of tumor cells counted. For statistical analysis, scores were later dichotomized to a score of 'negative' or 'positive' staining. For cytoplasmic or membrane staining a value of $10 \%$ was required before a case was accepted as positive. In the case of nuclear staining the threshold was $5 \%$, as in our series only a low percentage of nuclei were specifically labeled.

Statistical analysis. We analyzed the relationship between the expression of the different antigens and known prognostic factors in lung cancer: sex, age, histological type, tumor size (T), type of surgery (pneumonectomy, segmentomy, lobectomy, bilobectomy) and smoking habit. For these analyses we used $\chi^{2}$ and Fisher's exact test (when size was $<5$ ). The Spearman test was used for correlation analysis. A difference of $\mathrm{p}<0.05$ was considered as significant.

The Kaplan-Meier method was used to estimate survival, defined as the time between tumor diagnosis and the patient's death or last contact in five years. In univariate survival analyses, two-sided log-rank test (LR) for equality of survivor functions were used to assess the prognostic significance of different parameters on antigen positivity.

In order to identify factors associated with antigen positivity, we controlled potential confounders (such as age, sex, tumor size, histology and smoking habit) employing logistic regression.

Multivariate analysis was performed using the stepwise Cox proportional hazards model to evaluate the predictive power of each variable independently of the others. We used a model starting with the Cox model containing all variables
Table II. Immunostaining of NSCLC tumors against ER $\alpha$ and ERß according to their subcellular localization.

\begin{tabular}{lccc}
\hline & \multicolumn{3}{c}{ Subcellular localization } \\
\cline { 2 - 4 } Immunostaining & Cytoplasm & Nuclear & $\begin{array}{c}\text { Total } \\
\text { (cytoplasm and/or } \\
\text { nuclear) }\end{array}$ \\
\hline ER $\alpha$ & $41 / 58^{\mathrm{a}, \mathrm{b}}$ & $22 / 58^{\mathrm{a}}$ & $45 / 58$ \\
& $(70.7)$ & $(37.9)$ & $(77.6)$ \\
ERß & $37 / 58^{\mathrm{b}}$ & $23 / 58$ & $44 / 58$ \\
& $(63.8)$ & $(39.7)$ & $(75.9)$ \\
\hline
\end{tabular}

${ }^{\mathrm{a}, \mathrm{b}}$ Significantly correlated (Spearman test, $\mathrm{p}<0.05$ ).

and successively eliminating the least statistically significant variable until only statistically significant variables were left $(\mathrm{p}<0.05)$. All variables were entered in the multivariate analysis as categorical ones. SPSSPC+ (version 11) for Windows software was used for the aforementioned analyses.

\section{Results}

Expression of receptors for steroid hormones and for EGF in NSCLC tissues. The expression of ER $\alpha$ and ER $\beta$ were studied in 58 NSCLC samples from stage I patients who had undergone surgery as monotherapy. Specific subcellular staining, at nuclear and cytoplasmic level, was independently recorded. In the case of $\mathrm{ER} \alpha$, two different antibodies were employed to immunostain the lung cancer tissue, but only the anti-ER $\alpha$ able to recognize the $\mathrm{COOH}$-terminal epitope, stained the paraffin-embedded sections of lung tumors in a specific way.

As shown in Table II, we found that about $65-70 \%$ of NSCLC samples expressed ER $\alpha$ or ER $\beta$ at cytoplasmic level, while 37.9 and $39.7 \%$ of them expressed nuclear ER $\alpha$ or ERß respectively. Next, we analyzed the number of NSCLC tissue samples that expressed ER $\alpha$ or ERß, independently of their subcellular localization (defined as total ER $\alpha$ or total ERß expression). As shown in Table II, a high percentage of samples (about $75 \%$ ) showed staining for total ER $\alpha$ or total ERß. Conversely, we determined that a high percentage of NSCLC samples stained for at least one ER isoform at nuclear level (nuclear ER $\alpha / \beta)(13.8 \%$ expressed both receptors, $50.0 \%$ presented one of the ER and $36.2 \%$ were completely negative for nuclear $\mathrm{ER} \alpha / \beta)$.

Regarding the expression of PR, we found that only $12.1 \%(7 / 58)$ of NSCLC samples showed nuclear staining, while PR expression at cytoplasmic level was not found in any sample. When EGFR expression was analyzed, 36/58 tumors $(62.1 \%)$ showed staining of tumor cells at membrane level.

As biological interactions have been described for most of these molecules, we next analyzed whether there was any correlation with statistical significance between the levels of expression of the different molecules and according to their 
Table III. ER $\alpha, E R ß, P R$ and EGFR expressions according to the main features with clinical relevance in lung cancer.

\begin{tabular}{|c|c|c|c|c|c|c|}
\hline Parameter $^{\mathrm{a}}$ & $\begin{array}{c}\text { Nuclear } \mathrm{ER} \alpha^{+} / \\
\text {total }(\%)\end{array}$ & $\begin{array}{c}\text { Cytoplasmic } \mathrm{ER} \alpha^{+} / \\
\text {total }(\%)\end{array}$ & $\begin{array}{l}\text { Nuclear } E R \beta^{+} / \\
\text {total }(\%)\end{array}$ & $\begin{array}{c}\text { Cytoplasmic } \mathrm{ER}^{+} / \\
\text {total }(\%)\end{array}$ & $\begin{array}{c}\mathrm{PR}^{+} / \\
\text {total }(\%)\end{array}$ & $\begin{array}{l}\mathrm{EGFR}^{+/} \\
\text {total }(\%)\end{array}$ \\
\hline \multicolumn{7}{|l|}{ Sex } \\
\hline Male & $17 / 40(42.5)$ & $27 / 40(67.5)$ & $15 / 40(37.5)$ & $24 / 39(61.5)$ & $6 / 40(15.0)$ & $25 / 40(62.5)$ \\
\hline Female & $5 / 18(27.8)$ & $14 / 18(77.8)$ & 8/18 (44.4) & $12 / 18(66.7)$ & $1 / 18(5.6)$ & $11 / 18(61.1)$ \\
\hline \multicolumn{7}{|l|}{ Age } \\
\hline$<60$ & $11 / 14(78.6)$ & $12 / 14(85.7)$ & $5 / 14(35.7)$ & $9 / 14(64.3)$ & $1 / 14(7.1)$ & $8 / 14(57.1)$ \\
\hline $60-69$ & 6/31 (19.4) & $20 / 31(64.5)$ & $13 / 31(41.9)$ & $19 / 30(63.3)$ & 3/31 (9.7) & $21 / 31(67.7)$ \\
\hline$\geq 70$ & $5 / 12(41.7)^{\mathrm{b}}$ & $8 / 12(66.7)$ & $5 / 12(41.7)$ & $8 / 12(66.7)$ & $3 / 12(25.0)$ & $6 / 12(50.0)$ \\
\hline \multicolumn{7}{|l|}{ Stage } \\
\hline IA & $7 / 22(31.8)$ & $19 / 22(86.4)$ & $10 / 22(45.5)$ & $14 / 22(63.6)$ & $1 / 22(4.5)$ & $15 / 22(68.2)$ \\
\hline IB & 15/36 (41.7) & $22 / 36(61.1)^{b}$ & $13 / 36(36.1)$ & $22 / 35(62.9)$ & 6/36 (16.7) & $21 / 36(58.3)$ \\
\hline \multicolumn{7}{|l|}{$\begin{array}{l}\text { Histological } \\
\text { type }\end{array}$} \\
\hline $\mathrm{SCC}$ & $9 / 18(50.0)$ & $10 / 18(55.6)$ & $6 / 18(33.3)$ & $10 / 18(55.6)$ & $1 / 18(5.6)$ & $12 / 18(66.7)$ \\
\hline $\mathrm{ADC}$ & $12 / 33(36.4)$ & 28/33 (84.8) & $14 / 33(42.4)$ & $24 / 32(75.0)$ & $5 / 33(15.2)$ & $19 / 33(57.6)$ \\
\hline Others & 1/6 (16.7) & $2 / 6(33.3)^{b}$ & $3 / 6(50.0)$ & 2/6 (33.3) & $1 / 6(16.7)$ & $4 / 6(66.7)$ \\
\hline \multicolumn{7}{|l|}{ Surgery } \\
\hline Lobectomy & $17 / 43(39.5)$ & $30 / 43(69.8)$ & $17 / 43(39.5)$ & $27 / 42(64.3)$ & $7 / 43(16.3)$ & $27 / 43(62.8)$ \\
\hline Bilobectomy & $1 / 4(25.0)$ & $1 / 4(25.0)$ & $2 / 4(50.0)$ & $2 / 4(50.0)$ & $0 / 4(0)$ & $3 / 4(75.0)$ \\
\hline Pneumonectomy & $3 / 3(100)$ & $3 / 3(100)$ & $0 / 3(0)$ & 2/3 (66.7) & $0 / 3(0)$ & $1 / 3(33.3)$ \\
\hline Segmentectomy & $1 / 8(12.5)$ & 7/8 (87.5) & $4 / 8(50.0)$ & $5 / 8(62.5)$ & 0/8 (0) & $5 / 8(62.5)$ \\
\hline \multicolumn{7}{|l|}{ Smoking habit } \\
\hline No & $5 / 16(31.3)$ & $13 / 16(81.3)$ & $6 / 16(37.5)$ & $11 / 16(68.8)$ & $1 / 16(6.3)$ & $8 / 16(50.0)$ \\
\hline Yes & $16 / 41(39.0)$ & 27/41 (65.9) & $17 / 41(41.5)$ & 25/41 (61.0) & $5 / 41(12.2)$ & $27 / 41(65.9)$ \\
\hline
\end{tabular}

${ }^{a}$ Where columns do not sum to the total, data were missing or unknown. ${ }^{b} \mathrm{p}<0.05, \chi^{2}$ test.

subcellular localization. A weak, although significant association between the expression of nuclear ER $\alpha$ and cytoplasmic ER $\alpha$ was observed, employing a bivariate correlation test (Spearman test, $\mathrm{p}<0.05$ ). In addition, a significant correlation between the expression of ER $\alpha$ and ER $\beta$ at cytoplasmic level was found (Spearman test, $\mathrm{p}<0.01$ ). On the contrary, there was no association between the expression of $\mathrm{ER} \alpha$ and $\mathrm{ER} \beta$ at nuclear level.

The expression of EGFR did not correlate either with $\mathrm{PR}$ or ER $\alpha$ immunostaining, at any localization. However, we found a weak, although significant, association between EGFR and nuclear ERß expression (Spearman test, $\mathrm{p}<0.05$ ).

Association between the expression of steroid and EGF receptors and relevant clinico-pathological features in lung cancer. Possible relationships between antigen immunostainings and clinicopathological features relevant in the prognosis of NSCLC patients were summarized in Table III. Cytoplasmic ER $\alpha$ expression was associated with tumor size (86.4\% in T1 tumors vs. $61.1 \%$ en T2, $\left.\chi^{2}, \mathrm{p}=0.04\right)$. Besides, statistic analysis indicated that cytoplasmic ER $\alpha$ was found more frequently in ADC than in SCC tumors $\left(\chi^{2} \mathrm{p}<0.05\right)$.
However, logistic regression indicated that this association disappeared when other prognostic factors were included in the multivariate analysis (data not shown). We also found that nuclear immunostaining for ER $\alpha$ expression decreased with age (Spearman test, $\mathrm{p}<0.001$ ).

No statistically significant association was found between total $\mathrm{ER} \alpha$, total $\mathrm{ER} \beta$, nuclear $\mathrm{ER} \alpha / \beta$ or PR status and sex, age, histology, tumor size, differentiation grade or smoking habit. Finally, we found that EGFR expression was associated with smoking habits (Spearman test, $\mathrm{p}<0.01$ ).

Uni- and multivariate analysis between the expression of steroid and EGF receptors and overall survival. Univariate analysis indicated that the lack of nuclear ERß was associated with bad prognosis (Fig. 1). Multivariate Cox analysis confirmed that this association maintained the statistical significance when other prognostic variables in lung cancer were included. Table IV shows the final model, with the variables that have shown to be significant.

The absence of membrane EGFR expression was also associated with a worse outcome, as shown in Fig. 2. Multivariate Cox final model showed that this association was 


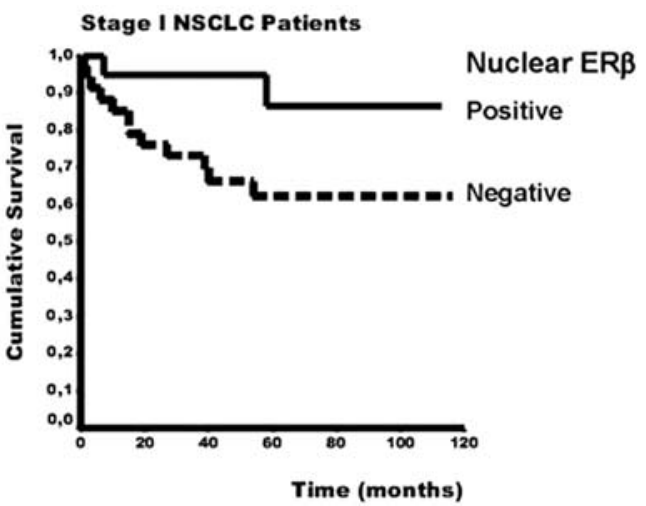

Figure 1. Kaplan-Meier curves of overall survival categorized by nuclear ERß labelling index in stage I NSCLC patients. Patients $2 / 22(9.1 \%)$, whose tumors showed immunopositivity for nuclear ERß and 12/35 (34.3\%) patients with negative tumors died. Difference in survival was statistically significant (log-rank test 3.79, p<0.05). Tumors positive $(-)$ or negative (- - ) for ERß immunostaining.

independent of other prognostic variables relevant in NSCLC (Table V). On the other hand, the expression of ER $\alpha$ at any subcellular localization, cytoplasmic or total ER $\alpha$, nuclear $\mathrm{ER} \alpha / \beta$ or PR did not seem to be relevant as prognosis factors of global survival, in this population of stage I NSCLC patients (data not shown).

Next, NSCLC patients were sub-classified according to the expression of both molecules: nuclear ERß and/or EGFR, to determine whether the combination of both biomarkers could be a better predictor of survival than each one separately. NSCLC tumors negative for both, nuclear ERß and EGFR were defined as 'double negative tumors'. Univariate analysis showed a significant correlation between global survival and the expression of nuclear ERß/EGFR (LR test 8.15, $\mathrm{p}<0.05$ ) (data not shown). As a deeper statistical analysis did not show differences in the overall survival between NSCLC patients with $\mathrm{ER}^{+} / \mathrm{EGFR}^{+}$and $\mathrm{ER} \beta^{+} / \mathrm{EGFR}$ - tumors and the number of $\mathrm{ER}^{+} / \mathrm{EGFR}^{-}$cases was very low, we decided to join both groups (nuclear $\mathrm{ER}^{+}$and $\mathrm{EGFR}^{+/-}$tumors). Then, we analyzed the survival curves of the three groups: i) $\mathrm{ER} \beta^{+}$ and $\mathrm{EGFR}^{+-}$; ii) $\mathrm{ER}^{-}$and $\mathrm{EGFR}^{+}$; and iii) $\mathrm{ER}^{-}$and $\mathrm{EGFR}^{-}$ (double negative). The LR test indicated high statistical differences in survival among these groups (Fig. 3, LR 7.91,

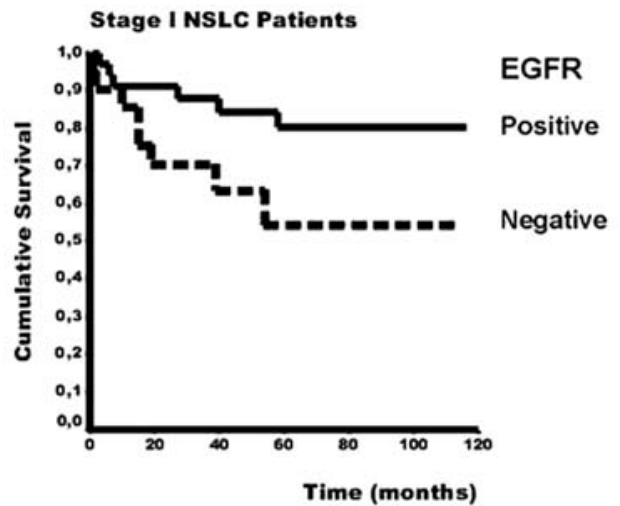

Figure 2. Kaplan-Meier curves of overall survival categorized by membrane EGFR labelling index in stage I NSCLC patients (log-rank test 3.78, $\mathrm{p}<0.05)$. Patients $6 / 36(16.7 \%)$, whose tumors showed immunopositivity for nuclear ERß and 8/21 (38.1\%) patients with negative tumors died. Tumors positive (-) or negative (- - ) for EGFR immunostaining.

$\mathrm{p}<0.001)$. Thus, we found that double negative stage I NSCLC patients had a significantly worse prognosis, as $47.06 \%(8 / 17)$ of them died during the study period. Conversely, patients whose tumors were $\mathrm{ER}^{+}$and $\mathrm{EGFR}^{+/-}$showed the best outcome, as only $9.09 \%(2 / 22)$ died.

\section{Discussion}

Some studies support the concept that sex steroid and EGFR receptors have key roles in normal lung biology and also in lung cancer $(31,35)$. Our specific aim was to study the expression of sex steroid receptors (ER $\alpha, E R \beta$ and PR) and EGFR in NSCLC tumor in a cohort of stage I patients that had undergone surgical resection of their tumors, as monotherapy, and to determine whether their expression correlated with lung cancer clinico-pathological features and with overall survival. This population of stage I NSCLC patients seems to be representative, since survival studies demonstrated that male gender and large tumor size, known bad prognosis factors, were associated with a worse outcome (data not shown).

Here, we report new findings that may contribute to the clinical management of stage I NSCLC patients. Our results can be synthesized in three main points: i) a high percentage

Table IV. Cox survival model for ERß expression in stage I NSCLC patients, taking into account the known prognostic clinico-pathological parameters in lung cancer.

\begin{tabular}{lcccc}
\hline Independent variable & Coefficient & P-value & Relative risk & 95\% Confidence interval \\
\hline Sex & -3.159 & 0.015 & 0.042 & $0.003-0.54$ \\
Smoking habit & -2.660 & 0.017 & 0.07 & $0.01-0.62$ \\
Nuclear ERß & -2.844 & 0.009 & 0.06 & $0.01-0.49$ \\
\hline
\end{tabular}

The variables entered in the multivariate analysis were age, sex, tumor size, histological type, type of surgical and smoking habit. The table shows the significant variables in the equation of nuclear ERß. Both the histological type and the tumoral size showed a relative risk of about 4.5 with a borderline significance, $\mathrm{p}<0.07$ and 0.06 respectively. Reference values: sex, male; smoking habit, smoker; nuclear ERß, negative expression. 
Table V. Cox multivariate study showing the effect of known clinico-pathological parameters in the global survival of the studied NSCLC patients.

\begin{tabular}{lcccc}
\hline Independent variable & Coefficient & P-value & Relative risk & 95\% Confidence interval \\
\hline Smoking habit & -3.166 & 0.013 & 0.04 & $0.01-0.52$ \\
EGFR & -2.924 & 0.002 & 0.05 & $0.01-0.35$ \\
\hline
\end{tabular}

The variables entered in the multivariate analysis were the same as those indicated in the legend of Table IV. The table shows the significant variable in the equation of EGFR expression. Reference values: smoking habit, smoker; EGFR, negative expression.

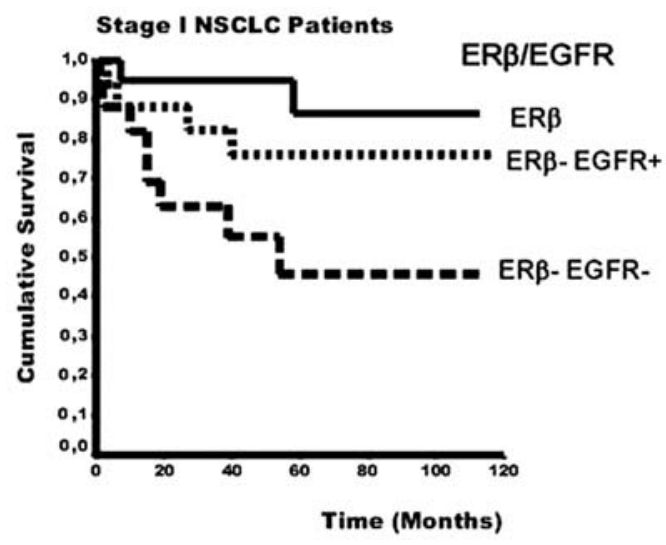

Figure 3. Kaplan-Meier curves of overall survival categorized according to the simultaneous expression of nuclear ERß and EGFR labelling index in stage I NSCLC patients (log-rank test 7.91, $\mathrm{p}<0.001)$. Tumors immunopositive for nuclear ERß $(\mathrm{n}=22)(-)$, tumors negative for ERß and positive for EGFR $(\mathrm{n}=18)(--)$ and double negative tumors $(\mathrm{n}=17)\left(\mathrm{ER} \beta^{-}\right.$and EGFR ${ }^{-}(--)$.

of tumors expressed both ER ( $\alpha$ and $\beta$ ) and EGFR receptors; ii) the lack of EGFR and nuclear ERß expression could be considered independent markers of poor outcome; and iii) the simultaneous lack of EGFR and nuclear ERß seems to be a better predictor of prognosis than each biomarker independently.

Previous studies support the selection of these molecules as possible prognosis biomarkers. It is nowadays accepted that estrogens are relevant in the homeostasis of the lung and may have a role in initiating and maintaining the growth of lung cancer $(28,36)$. In addition, recent studies have provided evidence about a functional interaction between ER and EGFR pathways in different tissues, including lung cancer $(34,37)$. In this sense, it was proved that the combined targeting of ER and EGFR in NSCLC cells showed higher antiproliferative effects than those obtained independently (34).

As it is now accepted that ERs are functional both at nuclear and extranuclear level $(12,38)$, we recorded ER expression at nuclear and cytoplasmic localization in an independent way in our NSCLC samples. We demonstrated, employing an immunohistochemical technique, that NSCLC tumors expressed both isoforms of estrogen receptors ER $\alpha$ and ERß. In the case of nuclear ER staining, we found that about $38-40 \%$ of tumors presented ER $\alpha$ or ERß immunopositivity. However, if we consider the expression of both receptors at nuclear level, about $64 \%$ of the samples showed at least one of these two isoforms. On the other hand, in the present study, we observed that extranuclear expression of ER occurs frequently, as we found cytoplasmic ER $\alpha$ and ERß immunoreactivities in $64-70 \%$ of NSCLC tumors. Only a few studies have reported extranuclear immunostaining $(21,26,30)$, being our results similar to those reported by Marquez-Garbán et al (26) regarding the levels of nuclear and extranuclear ER $\alpha$ and ERß expression. Our observations did not agree with those of other authors $(21,28)$, who reported that ER $\alpha$ was located primarily in the cytoplasm, while ERß was probably the predominant nuclear receptor of normal lung and cancer samples.

There is discrepancy in the literature regarding the percentage of samples that express ER $\alpha$. While some authors have detected little or no expression of ER $\alpha(19,23)$, others, as we did, have found staining for ER $\alpha$ in a high number of lung cancer tumors $(26,30)$. In fact, the finding that specific immunostaining was obtained only when we employed an anti-ER $\alpha$ raised against epitopes in the $-\mathrm{COOH}$ terminus could explain the differences among different authors. Other studies also report that, in the case of lung tissues, no or little reactivity to $\mathrm{ER} \alpha$ was observed when an antibody against the -NH2 terminus was used (21). An explanation for this could be that the antibody recognizes epitopes in exons that are deleted in $\mathrm{ER} \alpha$ (39) or that the antibody recognizes a conformation of the $\mathrm{ER} \alpha$ protein specific for other tissues such as breast, but absent in the lung.

In the case of ERß most of the studies showed some degree of expression for this isoform (19,22-26,28-30), suggesting its predominance in the lung.

We did not find any association between the expression of ERs and gender, similar to Marquez-Garbán et al (26), while other authors reported that the expression of ERs in lung cancer is gender-dependent $(19,29)$.

We also analyzed the expression of PR in the same group of lung cancer cases. PR immunoreactivity was detected only in the nuclei of NSCLC cells in a limited number of cases. Methodological aspects could explain the differences between our results and those of other authors who found either no reactivity (20) or up to about $63 \%$ of PR expression in NSCLC tumors (30).

On the other hand, as the EGF receptor family including HER1 and HER2 is implicated in lung cancer pathogenesis and progression (31) and as EGFR antibodies or tyrosine kinase inhibitors impair the growth of lung tumors expressing 
these receptors (40), we also analyzed the expression of EGFR (HER1). We found that more than $60 \%$ of the samples showed specific EGFR staining at membrane level $(\geq 10 \%$ of positive cells). Several studies have analyzed the expression of EGFR in lung cancer, finding overexpression, defined in general as higher than $10 \%$ of immunopositive cells, in $13-80 \%$ of the cases (41-43).

There are some studies examining ER $\alpha$ and ERß expressions as prognostic factors in terms of overall survival in NSCLC $(19,21,25,30)$. In the present study we determined that the lack of nuclear ERß was associated with bad prognosis. Interestingly, this receptor has been related with antiproliferative effects (44). In coincidence with us, Kawai et al found that the absence of ERß could be an independent factor predictive of poor disease outcome (21). In addition, Schwartz et al found that lack of nuclear ERß expression was associated with worse survival, but only in a male population with lung cancer (19). We did not find any correlation between the expression of ER $\alpha$ and prognosis, contrarily to Kawai et al who found that its overexpression was associated with poor outcome (21). In addition, Raso et al found that the expression of ER did not correlate with overall survival, although they found that cytoplasmic overexpression of ER $\alpha 4$ was associated with worse recurrence-free survival (30). Our study also determined that PR status was not useful to predict the outcome of the NSCLC patients, similar to Raso et al (30). Another study reported that the lack of PR was strongly associated with better clinical outcome in a population that includes all TNM stages (18).

Regarding EGFR, we found that its lack is an independent factor of poor prognosis in our population of stage I NSCLC patients. This result contrasts with those of other reports, as most of them found that EGFR is not a prognostic factor in NSCLC, while a small percentage associated EGFR overexpression with poor outcome $(32,43,45)$. In agreement with us, Rusch et al found that low EGFR expression was associated with worse overall survival in a univariate study (46).

As previously mentioned, it is now known that sex steroid hormones establish crosstalk with growth factor-signaling pathways, such as those generated by activated membrane receptors of the HER family (34). Taking into account that, in our population, both the lack of ERB and of EGFR was associated with poor prognosis, we analyzed the power of double negativity (nuclear ERß- and EGFR-) on patient survival. We found that early stage NSCLC patients with double negative tumors are at a higher risk of death and that this condition seems to predict the patient outcome in a better way than each biomarker individually. Interestingly, all double negative stage I NSCLC cases who died were also PR negative. However, due to the small number of positive PR tumors found, further studies are necessary to confirm this observation. In a similar way, in the last decade, several breast cancer subgroups that differ in their overall geneexpression profile were defined. One of them, the triplenegative phenotype, characterized by a lack of HER2 gene amplification (a molecule of the same family of receptors that EGFR) and a lack of estrogen and progesterone receptors expression, has the worst prognosis (47).

In conclusion, our analysis of sex steroid and EGFR receptors in stage I NSCLC suggests that this tumor could be potentially considered a hormone responsive tissue. So, the anti-estrogen treatment, combined with the targeting of EGFR, could be an interesting therapeutic option, that was explored by Traynor et al in a clinical pilot study (48). We have also demonstrated that lack of nuclear ERß and membrane EGFR immunostaining could be useful independent markers of poor global survival for stage I NSCLC patients. In addition, double negativity seems to be a better indicator to predict outcome than each biomarker individually. Although our study adds new information about lung cancer, we are aware of its limitations given the fact that the number of patients studied was not enough to detect strong associations when examining subgroups. However, we consider that our series is not dismissible, taking into account that it is a relatively large homogeneous population for a country without lung cancer screening programs and where the vast majority of patients are diagnosed at stages III or IV. It is our wish that, after validation in other oncology centers, the introduction of these molecular marker assessments into routine clinical management of NSCLC, is eventually made.

\section{Acknowledgements}

We would like to acknowledge Fernanda Roca for her skill in histological and immunohistochemistry techniques. This work was supported by grants from the SECYT (PICT 11217) and the University of Buenos Aires (UBACYT M003).

\section{References}

1. Matos E and Loria D: Atlas de Mortalidad por Cáncer. Argentina 1997-2001. Buenos Aires, 2003.

2. Rom WN, Hay JG, Lee TC, Jiang Y and Tchou-Wong KM: Molecular and genetic aspects of lung cancer. Am J Respir Crit Care Med 161 (4 Pt 1): 1355-1367, 2000.

3. Walsh GL, O'Connor M, Willis KM, Milas M, Wong RS, Nesbitt JC, Putnam JB Jr, Lee JJ and Roth JA: Is follow-up of lung cancer patients after resection medically indicated and cost-effective? Ann Thorac Surg 60: 1563-1570, 1995.

4. Osborne CK and Schiff R: Estrogen-receptor biology: continuing progress and therapeutic implications: J Clin Oncol 23: 1616-1622, 2005.

5. Scobie GA, Macpherson S, Millar MR, Groome NP, Romana PG and Saunders PT: Human oestrogen receptors: differential expression of ER alpha and beta and the identification of ER beta variants. Steroids 67: 985-992, 2002.

6. Barkhem T, Carlsson B, Nilsson Y, Enmark E, Gustafsson J and Nilsson S: Differential response of estrogen receptor alpha and estrogen receptor beta to partial estrogen agonists/antagonists. Mol Pharmacol 54: 105-112, 1998.

7. Cowley SM, Hoare S, Mosselman S and Parker MG: Estrogen receptors alpha and beta form heterodimers on DNA. J Biol Chem 272: 19858-19862, 1997.

8. Horwitz KB, Jackson TA, Bain DL, Richer JK, Takimoto GS and Tung L: Nuclear receptor coactivators and corepressors. Mol Endocrinol 10: 1167-1677, 1996.

9. Pietras RJ, Marquez DC, Chen HW, Tsai E, Weinberg O and Fishbein M: Estrogen and growth factor receptor interactions in human breast and non-small cell lung cancer cells. Steroids 70: 372-381, 2005.

10. Yamaguchi Y: Microenvironmental regulation of estrogen signals in breast cancer. Breast Cancer 14: 175-181, 2007.

11. Lehnes K, Winder AD, Alfonso C, Kasid N, Simoneaux M, Summe H, Morgan E, Iann MC, Duncan J, Eagan M, Tavaluc R, Evans CH Jr, Russell R, Wang A, Hu F and Stoica A: The effect of estradiol on in vivo tumorigenesis is modulated by the human epidermal growth factor receptor 2/phosphatidylinositol 3-kinase/Akt1 pathway. Endocrinology 148: 1171-1180, 2007. 
12. Osborne CK, Shou J, Massarweh S and Schiff R: Crosstalk between estrogen receptor and growth factor receptor pathways as a cause for endocrine therapy resistance in breast cancer. Clin Cancer Res 11 (2 Pt 2): S865-S870, 2005.

13. Kato S, Endoh H, Masuhiro Y, et al: Activation of the estrogen receptor through phosphorylation by mitogen-activated protein kinase. Science 270: 1491-1494, 1995.

14. Bardou VJ, Arpino G, Elledge RM, Osborne CK and Clark GM: Progesterone receptor status significantly improves outcome prediction over estrogen receptor status alone for adjuvant endocrine therapy in two large breast cancer databases. J Clin Oncol 21: 1973-1979, 2003.

15. Clarke CL and Sutherland RL: Progestin regulation of cellular proliferation. Endocr Rev 11: 266-301, 1990.

16. Ollayos CW, Riordan GP and Rushin JM: Estrogen receptor detection in paraffin sections of adenocarcinoma of the colon, pancreas, and lung. Arch Pathol Lab Med 118: 630-632, 1994.

17. Stedman KE, Moore GE and Morgan RT: Estrogen receptor proteins in diverse human tumors. Arch Surg 115: 244-248, 1980.

18. Ishibashi H, Suzuki T, Suzuki S, Niikawa H, Lu L, Miki Y, Moriya T, Hayashi S, Handa M, Kondo T and Sasano H: Progesterone receptor in non-small cell lung cancer, a potent prognostic factor and possible target for endocrine therapy. Cancer Res 65: 6450-6458, 2005

19. Schwartz AG, Prysak GM, Murphy V, Lonardo F, Pass H, Schwartz J and Brooks S: Nuclear estrogen receptor beta in lung cancer: expression and survival differences by sex. Clin Cancer Res 11: 7280-7287, 2005.

20. Radzikowska E, Langfort R and Giedronowicz D: Estrogen and progesterone receptors in non small cell lung cancer patients. Ann Thorac Cardiovasc Surg 8: 69-73, 2002.

21. Kawai H, Ishii A, Washiya K, Konno T, Kon H, Yamaya C, Ono I, Minamiya Y and Ogawa J: Estrogen receptor alpha and beta are prognostic factors in non-small cell lung cancer. Clin Cancer Res 11: 5084-5089, 2005.

22. Dougherty SM, Mazhawidza W, Bohn AR, Robinson KA Mattingly KA, Blankenship KA, Huff MO, McGregor WG and Klinge CM: Gender difference in the activity but not expression of estrogen receptors alpha and beta in human lung adenocarcinoma cells. Endocr Relat Cancer 13: 113-134, 2006.

23. Omoto Y, Kobayashi Y, Nishida K, Tsuchiya E, Eguchi H, Nakagawa K, Ishikawa Y, Yamori T, Iwase H, Fujii Y, Warner M, Gustafsson JA and Hayashi SI: Expression, function, and clinical implications of the estrogen receptor beta in human lung cancers. Biochem Biophys Res Commun 285: 340-347, 2001.

24. Mollerup S, Jorgensen K, Berge G and Haugen A: Expression of estrogen receptors alpha and beta in human lung tissue and cell lines. Lung Cancer 37: 153-159, 2002.

25. Skov BG, Fischer BM and Pappot $\mathrm{H}$ : Oestrogen receptor beta overexpression in males with non-small cell lung cancer is associated with better survival. Lung Cancer 59: 88-94, 2008.

26. Marquez-Garbán DC, Chen HW, Fishbein MC, Goodglick L and Pietras R: Estrogen receptor signaling pathways in human non-small cell lung cancer. Steroids 72: 135-143, 2007.

27. Lau SK, Chu PG and Weiss LM: Immunohistochemical expression of estrogen receptor in pulmonary adenocarcinoma. Appl Immunohistochem Mol Morphol 14: 83-87, 2006.

28. Stabile LP, Davis AL, Gubish CT, Hopkins TM, Luketich JD, Christie N, Finkelstein S and Siegfried JM: Human non-smal cell lung tumors and cells derived from normal lung express both estrogen receptor alpha and beta and show biological responses to estrogen. Cancer Res 62: 2141-2150, 2002

29. Fasco MJ, Hurteau GJ and Spivack SD: Gender-dependent expression of alpha and beta estrogen receptors in human nontumor and tumor lung tissue. Mol Cell Endocrinol 188: 125-140, 2002.

30. Raso MG, Behrens C, Herynk MH, Liu S, Prudkin L, Ozburn NC, Woods DM, Tang X, Mehran RJ, Moran C, Lee JJ and Wistuba I: Immunohistochemical expression of estrogen and progesterone receptors identifies a subset of NSCLCs and correlates with EGFR mutation. Clin Cancer Res 15: 5359-5368, 2009.

31. Dei Tos AP: The biology of epidermal growth factor receptor and its value as a prognostic/predictive factor. Int J Biol Markers 22 (Suppl. 4): S3-S9, 2007.
32. Selvaggi G, Novello S, Torri V, Leonardo E, De Giuli P, Borasio P, Mossetti C, Ardissone F, Lausi P and Scagliotti GV: Epidermal growth factor receptor overexpression correlates with a poor prognosis in completely resected non-small-cell lung cancer. Ann Oncol 15: 28-32, 2004.

33. Ji H, Li D, Chen L, Shimamura T, Kobayashi S, McNamara K, Mahmood U, Mitchell A, Sun Y, Al-Hashem R, Chirieac LR, Padera R, Bronson RT, Kim W, Jänne PA, Shapiro GI, Tenen D, Johnson BE, Weissleder R, Sharpless NE and Wong KK: The impact of human EGFR kinase domain mutations on lung tumorigenesis and in vivo sensitivity to EGFR-targeted therapies. Cancer Cell 9: 485-495, 2006

34. Stabile LP, Lyker JS, Gubish CT, Zhang W, Grandis JR and Siegfried JM: Combined targeting of the estrogen receptor and the epidermal growth factor receptor in non-small cell lung cancer shows enhanced antiproliferative effects. Cancer Res 65: 1459-1470, 2005.

35. Siegfried JM, Hershberger PA and Stabile LP: Estrogen receptor signaling in lung cancer. Semin Oncol 36: 524-531, 2009.

36. Taioli E and Wynder EL: Endocrine factors and adenocarcinoma of the lung in women. J Natl Cancer Inst 86: 869-870, 1994

37. Ignar-Trowbridge DM, Pimentel M, Parker MG, McLachlan JA and Korach KS: Peptide growth factor cross-talk with the estrogen receptor requires the $\mathrm{A} / \mathrm{B}$ domain and occurs independently of protein kinase $\mathrm{C}$ or estradiol. Endocrinology 137: 1735-1744, 1996.

38. Losel RM, Falkenstein E, Feuring M, Schultz A, Tillmann HC, Rossol-Haseroth $\mathrm{K}$ and Wehling $\mathrm{M}$ : Non-genomic steroid action: controversies, questions, and answers. Physiol Rev 83: 965-1016, 2003.

39. Huang A, Leygue E, Dotzlaw H, Murphy LC and Watson PH: Influence of estrogen receptor variants on the determination of ER status in human breast cancer. Breast Cancer Res Treat 58: 219-225, 1999.

40. Dongiovanni D, Daniele L, Barone C, Dongiovanni V, Fissore C, Sapino A, Macri L, Bussolati G, Buffoni L, Gaspari F, Grillo R, Birocco N, Addeo A, Ciuffreda L and Schena M: Gefitinib (ZD1839): therapy in selected patients with non-small cell lung cancer (NSCLC)? Lung Cancer 61: 73-81, 2008.

41. Meert AP, Martin B, Delmotte P, Berghmans T, Lafitte JJ, Mascaux C, Paesmans M, Steels E, Verdebout JM and Sculier JP: The role of EGF-R expression on patient survival in lung cancer: a systematic review with meta-analysis. Eur Respir J 20: 975-981, 2002.

42. Nicholson RI, Gee JM and Harper ME: EGFR and cancer prognosis. Eur J Cancer 37 (Suppl. 4): S9-S15, 2001.

43. Ludovini V, Bellezza G, Pistola L, Bianconi F, Di Carlo L, Sidoni A, Semeraro A, Del Sordo R, Tofanetti FR, Mameli MG, Daddi G, Cavaliere A, Tonato $M$ and Crino L: High coexpression of both insulin-like growth factor receptor-1 (IGFR-1) and epidermal growth factor receptor (EGFR) is associated with shorter disease-free survival in resected non-small-cell lung cancer patients. Ann Oncol 20: 842-849, 2009.

44. Lindberg MK, Moverare S, Skrtic S, Gao H, Dahlman-Wright K, Gustafsson JA and Ohlsson C: Estrogen receptor (ER)-beta reduces ERalpha-regulated gene transcription, supporting a 'ying yang' relationship between ERalpha and ERbeta in mice. Mol Endocrinol 17: 203-208, 2003.

45. Ohsaki Y, Tanno S, Fujita Y, Toyoshima E, Fujiuchi S, Nishigaki Y, Ishida S, Nagase A, Miyokawa N, Hirata S and Kikuchi K: Epidermal growth factor receptor expression correlates with poor prognosis in non-small cell lung cancer patients with p53 overexpression. Oncol Rep 7: 603-607, 2000.

46. Rusch V, Klimstra D, Venkatraman E, Pisters PW, Langenfeld J and Dmitrovsky E: Overexpression of the epidermal growth factor receptor and its ligand transforming growth factor alpha is frequent in resectable non-small cell lung cancer but does not predict tumor progression. Clin Cancer Res 3: 515-522, 1997.

47. Reis-Filho JS and Tutt AN: Triple negative tumours: a critical review. Histopathology 52: 108-118, 2008.

48. Traynor AM, Schiller JH, Stabile LP, Kolesar JM, Eickhoff JC Dacic S, Hoang T, Dubey S, Marcotte SM and Siegfried JM: Pilot study of gefitinib and fulvestrant in the treatment of postmenopausal women with advanced non-small cell lung cancer. Lung Cancer 64: 51-59, 2009. 